\title{
熱可塑性ポリエステルエラストマー成形品の変形挙動 一ハニカム型成形品の圧縮変形解析一
}

(第 29 巻第 5 号掲載)

磯貝悠美子*·古市謙 次*·住山环 哉* · 山下勝 久*·野々村千里*

熱可塑性ポリエステルエラストマーは, ゴムとエンジニア リングプラスチックの両方の特性を有しており，衝撃緩衝 材として建築用芯材，家具材，車両材などへの適用が進ん でいる。なかでもハニカム型構造を持つ落橋防止装置用の 緩衝材は，衝撃緩衝材としての代表的な用途の一つである。 八ニカム型構造は, 蜂の巣状の正六角形の断面を持つセ ルが多数集まった構造を有しており，そのセル壁の厚み， セルのサイズ等の構造パラメータの変更によって衝撃緩衝 材としてのエネルギー吸収性能を調整できる.

ハニカム型緩衝材に使用される素材としては，アルミニ ウムや複合材からなる薄肉のパネルを対象として，衝撃特 性に関する研究が報告されている。一方，樹脂単体から成 るハニカム型構造の衝撃緩衝材では, 成形の都合上そのセ ル壁がテーパを含んだ厚肉となる。そのため形状因子がエ ネルギー吸収性能に与える影響は，アルミハニカムのよう なセル壁が均一かつ薄肉のものよりも複雑になる.さらに これら形状の要因に加え, 樹脂材料そのものの複雑な力学 挙動のため, エネルギー吸収性能に与えるそれぞれの要因 の影響は充分に明らかにされていない.

熱可塑性ポリエステルエラストマーの優れた性能を生か し，八ニカム型緩衝材の用途を拡大するためには，複数の セルから構成される形状やセル壁のテーパ，吸収性能を調 節するために緩衝材の端面に施されたセル壁の切欠の役割 などを明確にすることが重要な課題の一つである．本研究 では，熱可塑性ポリエステルエラストマー製のハニカム型 構造の緩衝材を対象として，セル壁のテーパ構造や切欠が 緩衝材のエネルギー吸収特性（荷重－変位曲線）に及ぼす 影響について, 圧縮試験と理論解析, および有限要素法に よる数值解析を用いて以下のことを明らかにした。

Resume of the Paper Receiving the JSPP Best Paper Award 東洋紡(秼) 総合研究所
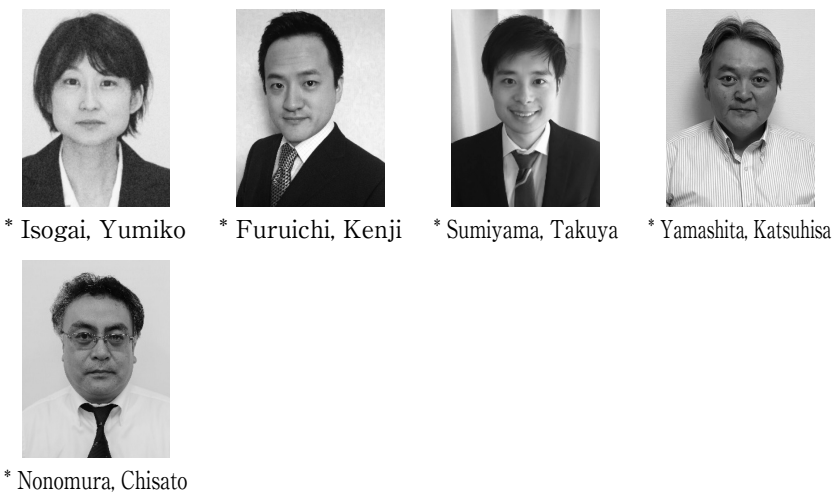

*Sumiyama, Takuya
（1）圧縮試験と理論解析による評価

一般的なハニカム型緩衝材の圧縮時における荷重一変位 曲線は, その特徵から, セル壁の弾性変形領域（領域 I ）, セル壁の塑性座屈変形を伴うプラトー領域（領域 II ）, セ ル壁の緻密化領域（領域 III）に分類できる。これら 3 つの 領域について，圧縮試験，理論解析による評価を実施した。

領域 I の弾性変形領域の荷重一変位曲線は, 単一のハニ カムセルの理論を複数セル用に拡張した理論を適用するこ とにより，圧縮子とセル壁の初期の接触面積のみから影響 を受けることが分かった。したがって，セル壁に施された 切欠は，初期の接触面積を減らすことで荷重の極大值を低 下させる役割を担うことになる。領域 II のプラトー領域に おいては，座屈変形によるセル壁の接触と厚みが影響する. このため，テーパ構造を無視してセル壁の均一厚みを仮定 する理論解析の結果は実成形品の荷重一変位曲線を正確に 表せないことを明確にした．また，領域IIIのセル壁の緻密 化の位置は，七ル壁のテーパ構造が接触箇所へ影響するた め，領域 II と同様に理論解析では実測を表すには不十分で あることがわかった。これらを踏まえると，有限要素法を 用いた荷重一変位曲線の評価が必要となる。

(2) 有限要素法による評価

八ニカム型緩衝材の有限要素法による数值解析的な評価 では，圧縮時のセル壁の座屈において曲げ変形の影響が大 きいため，構成則の材料定数は曲げ試験から同定しなけれ ばならない。そこで，実成形品から切り出した試験片の曲 げ試験から材料定数を決定した。

有限要素法による圧縮解析の結果，領域 I においては, 理論解析における評価と同様にセル壁の切欠が，初期荷重 の極大值を低下させることがわかった。つまり，切欠は周 辺部材に生じる衝撃荷重（最大荷重）を抑制する役割を果 たすことが明確に示された。また，領域 II， IIIにおいて， セル壁のテーパ構造はプラトー領域の荷重值，およびセル 壁が緻密化を開始する位置に影響を及ぼすことを明らかに した。このように，ハニカム型緩衝材の実製品形状を有限 要素法により正確にモデル化することにより, 圧縮試験に おける荷重の極大值とその時の変位量を定性的に再現する ことが可能となった。ただし，プラトー領域の荷重值およ びセル壁が緻密化を開始する位置の予測には，実測で得ら れる座屈モードの再現が課題として残る. 